\title{
THREE LETTERS BY TOLSTOJ
}

\section{Милый Суллер,}

Очень рад был получить ваше письмо. Сердце сердцу весть подает. Я вас тоже очень люблю. Я бы очень рад был если бы вас пристроить к Д. [ухоборам]. Я думаю что вы были бы им полезны. Я написал им о вас. Если они ответят что им нужен такой человек тогда надо будет написать письмо Голицыну м кот. [орое] вы свезете ему, чтоб он дал позволение ва быть с ними. Последнее что я знаю әто то что 3000 разс ленных сбираются ехать и запросили у пароходчиков цены за перевоз на о. [стров] Кипр. Хилков уехал на Кипр. Вот последние мои известия.

Анненкова разсказала мне про всех вас Н. Н. Е. И. и Вульфам передайте им всем мою любовь. Братски целую вас 13 Июля.

Л. Толстой

Открытое письмо.

Батум на Кавказе. Суллержицкому

До востребования.

Пожалуйста напишите мне сколько стоит переезд на пароходе от Батума до Америки, сколько на взрослого, на детей от 7 до 13 и безплатно ли дети ниже 7. Сколько можно выторговать и ляжет на голову семейных Напишите и обо всем что было. Не телеграфируйте. От телеграфа только путаница.

Открытое письмо.

Кавказ Батум.

Аңглийскому консулу

Получил ваше хорошее обстоятельное письмо, дорогой Суллер и послал его Ч. [ерткову] Нового знаю только то что Кипрские переехали в Аталассу и Бир. [юков] находит что Кипр не так неудобен как думали. Также думают и переехавшие. От Моода телеграмма чтобы выехали в Канаду 100 чел. [овек] Вы верно получили об зтом известие и распоряжение. Я только знаю. Напишите какие хотят переселяться прежде. Привет всем друзьям. Вас целую. 
34

Une lettre de Joseph Deyacque

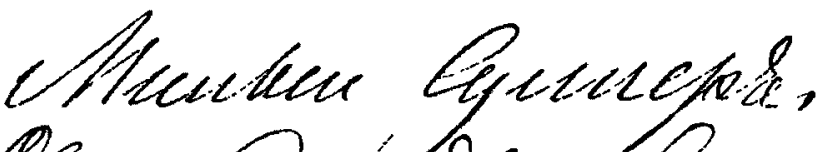

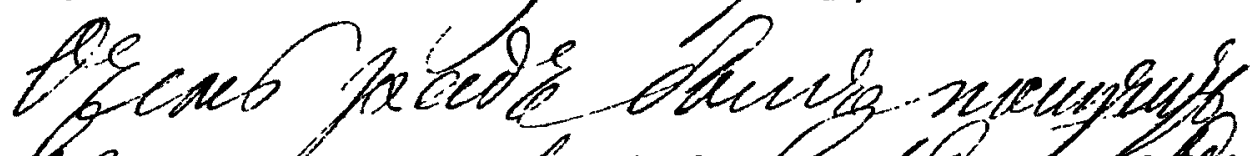

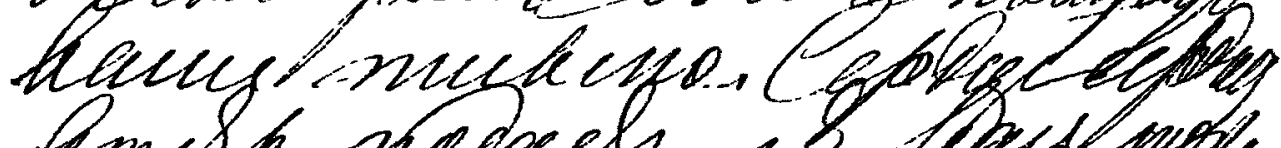

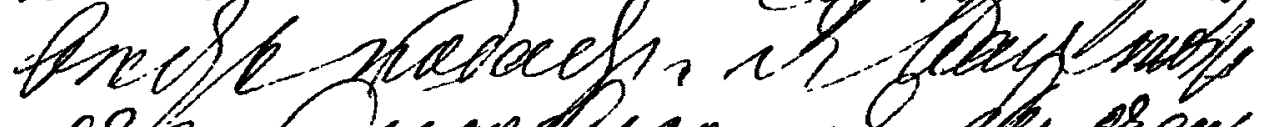

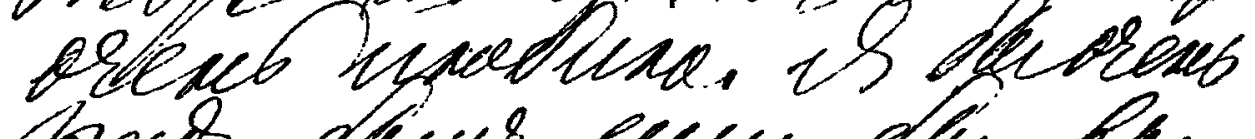

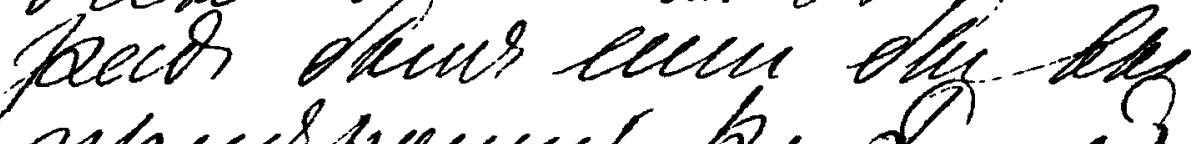

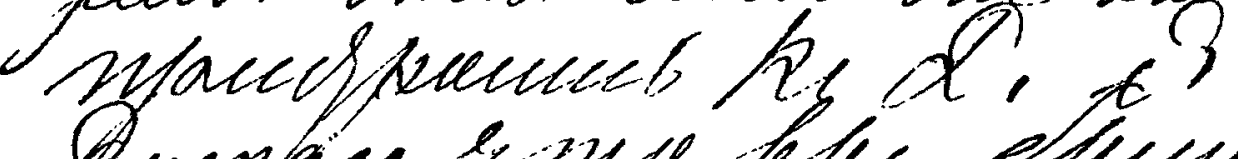

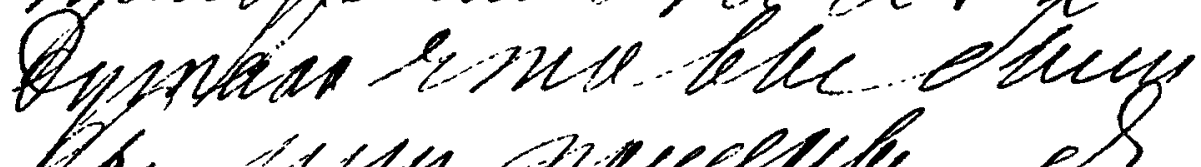
bas senn mouegala. os

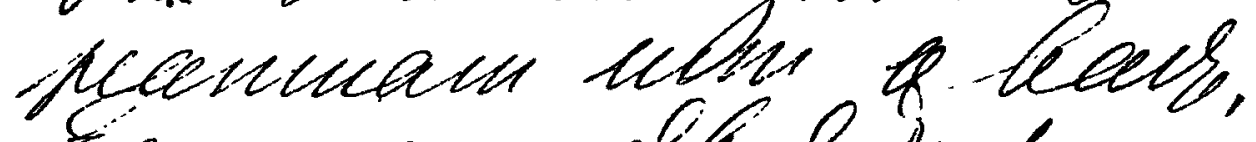
secu sum of lesphely inio went nupsene mlathen kew

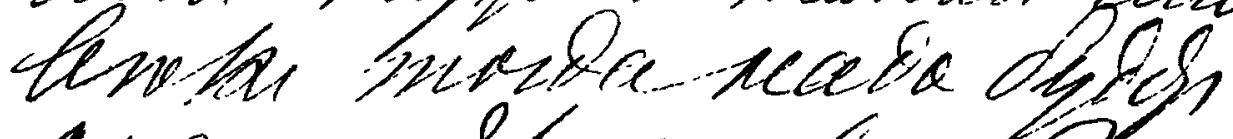

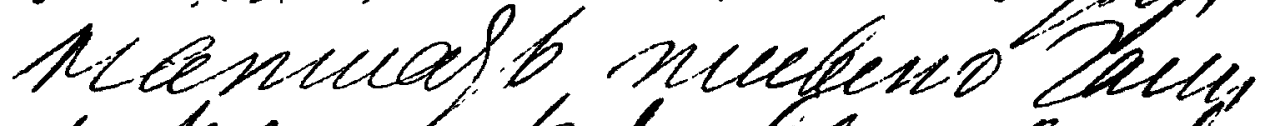

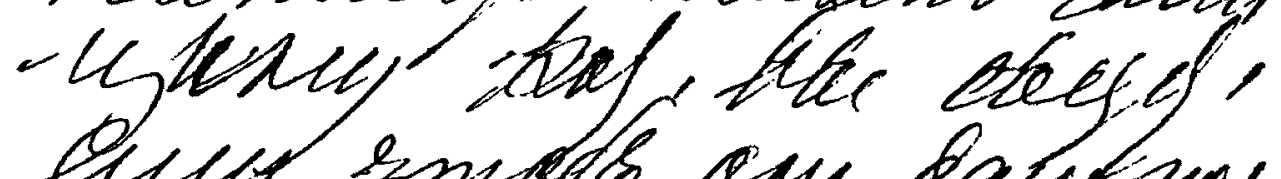
oun. snus om dafitrul tuseceric Reeun dw/ Resum,

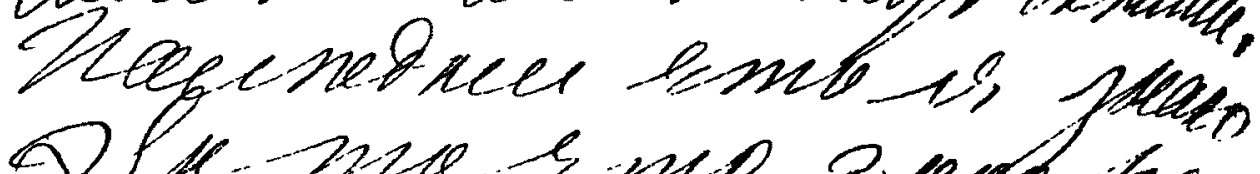

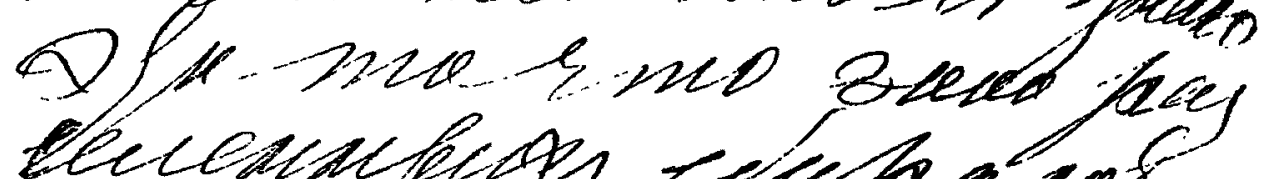

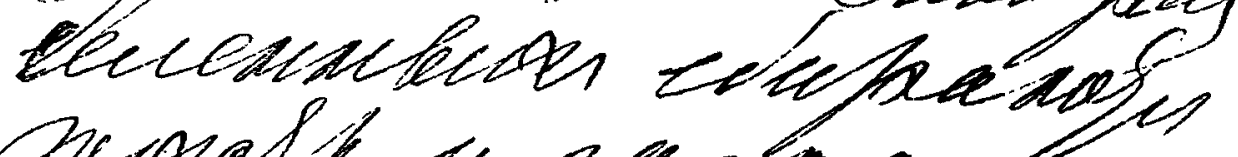

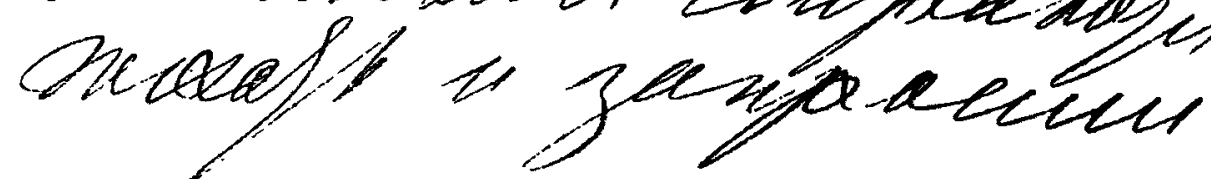


Dear Suller,

I was very glad to receive your letter. I also love you very much. I should be very glad to attach you to the duchobory. I think you would be useful to them. I wrote them about you. If they answer that they need such a person, then it will be necessary to write a letter to Golicyn, for you to take to him, to the effect that he give you permission to be with them. The latest $I$ know is that the 3000 unsettled persons are preparing to leave and have enquired at the shipping agency about prices for the voyage to the island of Cyprus. Chilkov went over to Cyprus. That is my latest news.

Annenkova told me all about you $\mathbf{N}$. To N. E. I. also the Wulfs give all my love. I kiss you brotherly.

July 13.

L. Tolstoj

Post-card.

Batum in the Caucasus.

to Suller žickij

poste restante.

Please write me how much the passage costs by steamboat from Batum to America how much per adult, for children from 7 to 13 and if children under 7 travel free of charge. How much reduction can you get and how does that work out per head for families. Write also about all that has happened. Don't telegraph. The telegrams only bring about confusion.

Post-card.

Caucasus, Batum.

To the English consul

For L.

I received your fine and detailed letter, dear Suller, and sent it on to Certkov. As to news I only know that the Cypriots went over to Atalassa and Birjukov finds Cyprus not so unpleasant as they had expected. The emigrants themselves are of the same opinion. From Maude a cable that 100 people were to leave for Canada. I suppose you received word and instruction about this. I only know it. Write which people want to emigrate first. Greetings to all friends. I kiss you.

L. T.

All three letters of Tolstoj, published here, are adressed to Leopol'd Antonovic Sulleržickij, and are written in connection with the emigration of the duchobory, in which, as is 
known, both of them took an active part. For neither of them was this the first contact with the duchobory. Indeed, to the public at large, the name of the duchobory is known in connection with Tolstoj only. And Sulleržickij visited the duchobory in the Caucasus in 1896 and '97, as he relates in an article (posešcenie duchoborov) in "Svobodnoe Slove" No. 2 (Onex près Genève 1899, pp. 141-157). But his active work for them began only in 1898, as is apparent from the first letter. It is evidently an answer to a letter of his, to Tolstoj, in which he offered his help with emigration, which was permitted by the government in the beginning of 1898. A satisfactory answer to the letter Tolstoj wrote to the duchobory was apparently soon received, for in the middle of August we see Sulleržickij already in the Caucasus. So, it seems, Golicyn made no objections.

The first letter is written on ordinary note paper. The envelope is missing and the year it was written in is not stated. This must have been 1898 . The International Institute possesses a copy of the letter from Sulleržickij to Tolstoj, in which he offers his services for the emigration. Moreover, Annenkova (Leonilla F.) mentioned in the letter, is stated in Tolstoj's diary for 1898 as arriving in Jasnaja Poljana on June 30th and leaving on July 5th (L. N. Tolstoi, Tagebuch erster Band 1895-1899, München 1917, p. 208, 211 and n. 97 p. 271). During this stay, only a few days before the letter was written, she no doubt told Tolstoj about Sulleržickij and the others. Who these others were, is not quite certain. The letter is not clear in this respect. Vul'fam in the Russian text cannot possibly be read as Vul'fach, and there is no dot after the word. It the last sentence is to begin with: peredajte, then the form Vul'fam makes no sense. If however the last sentence begins with; $i$ Vul'fam, the construction is rather bad; but in that case the possibility remains, that by the initials the Wulfs are meant. And indeed a friend of Tolstoj's of the name of $\mathrm{E}$. I. Wulf is known. The latter possibility therefore seems the most likely, but the restricted material at hand permits of no further conclusions.

The Chilkov mentioned is Prince Dmitrij Aleksandrovic 
Chilkov (1858-1914). In the previously quoted German edition of the diary (note 194) and in Letopisi gosudarstvennogo literaturnogo muzeja (No. 2, L. N. Tolstoj, M. 1938, p. 109) he is stated to have left Russia only in 1899. From this letter it is clearly seen that he left the country already in 1898. This fact is corroborated by Certkov (Listky svobodnogo slova no. 2, janvar' 1899 p. 22) and by Aylmer Maude in his biography of Tolstoj (part 2, New York 1910, p. 330) Moreover, one of the letters reproduced in Letopisi 2 was written by him in Montreal in 1898.

By razselennye are meant those duchobory that were driven from their homes already before emigration became possible, as distinguished from two other groups, in the Karsk and Elizavetpol'sk regions respectively, who remained in their homes until their emigration took place.

The Golicyn mentioned is general Prince Grigorij Sergeevic Golicyn (1838-1907), from 1897-1904 civil head of the Caucasus region.

When Sulleržickij went to the Caucasus, he arrived almost on the very day on which the first party left for Cyprus, so in the organisation of this voyage he practically had no hand. He concentrated on the organisation of the second party, to Canada, and in this connection the second letter was written. It shows that Tolstoj did not limit his efforts to the sending of money, but went into details for the financing of the project also. The information was written on a postcard and is undated. The postmark of Tula station is illegible. The postmark of arrival in Batum bears the date 18-VIII-1898, so the letter must have been written about August 10th. The signature is cut of, but the handwriting makes Tolstoj's authorship unmistakable.

In the organisation of the emigration, the English Consul in Batum, Patrick Stevens, took an active and helpful part. Possibly in order to speed up communications, Sulleržickij had the third letter addressed to him, who knew Sulleržickij's whereabouts during his travels amongst the duchobors better than Tolstoj.

This third letter is also undated. The Tula postmark is 
dated 11-IX-1898 and the Batum postmark 16-IX-1898. So the letter will have been written about 10th September. About that time Tolstoj may have received the first news from Cyprus from Birjukov, who had arrived there on August 17th (Russian style). The transport from Larnak to Atalassa took place about the 20th, and feelings about Cyprus were then still rather high, as Birjukov states in: Duchobory na Kipre, Svobodnoe Slovo no 2, 1899, p. 22ff.

The passage on Aylmer Maude points out, that already his first efforts in Canada met with succes. As Certkov states, he left for Canada at the end of August 1898 and, in general, the succes of his voyage was beyond expectations. It seems Maude's telegrafic instruction was not put into effect. From the publications on the emigration it is clear that the about 2000 emigrants on the "Lake Huron" were the first party to arrive in Canada. Maulde himself also wrote a book on the duchobory, which, to our regret, is not in the collection of the International institute, and which, consequently, we were not able to refer to here.

When asking which people wanted to go first, Tolstoj was thinking of the three groups of Duchobory in the Caucasus. Those wo went first were actually the "razselennye", already concentrated in Batum, whose need was more urgent still than that of the groups in the Karsk and Elizavetpol'sk regions, who still lived in their own places.

Together, these three letters once more bear witness of the deep and detailed interest Tolstoj took in the material as well as in the spiritual side of the problem of the duchobory and their emigration.

For practical reasons, the letters are published in the new orthography. The punctuation is given as in the original. The abbreviated words are given in [] .

J. M. 